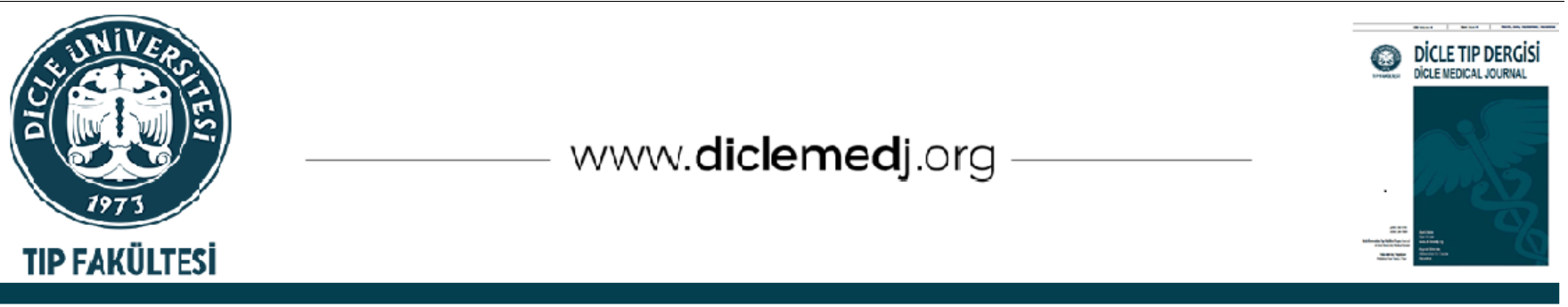

Original Article / Özgün Araştırma

\title{
The role of religiosity in the etiology of vaginismus in the light of socio-cultural features: The case of Turkey
}

\author{
Elif Aktan Mutlu ${ }^{1}{ }_{1}$, Mustafa Koc ${ }^{\text {iD }} 2$ \\ 1 Psychiatrist, Ministry of Health, Bursa City Hospital, Department of Psychiatry 16110, Bursa, Turkey \\ 2 Professor, Eskişehir Osmangazi University, Faculty of Theology, Department of Psychology of Religion, Eskisehir, Turkey
}

Received: 25.03.2021; Revised: 24.07.2021; Accepted: 27.07.2021

\begin{abstract}
Objective: Vaginismus is the most common female sexual dysfunction in Turkey and Middle East countries. Looking at the medical literature related to vaginismus, studies/patients have concentrated in the Middle east geographic area. Turkey is a developing, secular country located between Middle East and Europe with a mostly Muslim population. Many factors have been discussed in the etiology including psychosocial, cultural, biological and sexual causes. Religious beliefs of a person in the form of religiosity affect all social and spiritual spheres of his/her life in some way positively or negatively. One of the most affected life areas by religious beliefs is sexual life, which has a lots of taboos. In this study we aimed to compare religious belief levels that are thought to be effective in the etiology of vaginismus between patients and healthy controls and to discuss some of the other socio-cultural features.

Methods: 49 patients and 37 healthy volunteers were included. Sociodemographic data form, religious life scale and a form of common sexual myths were used as the measurement tools.

Results: No statistically significant difference was found between the participants with and without vaginismus in terms of education duration, working status, occupations, economical status, longest living place and marriage type ( $p>0.05$ for all). No statistically significant difference was found between the belief, emotions, behaviour, knowledge and total scores of both groups in terms of the presence of vaginismus ( $p>0.05$ for all).

Conclusions: In conclusion, most of the sociodemographic data involved in the etiology of vaginismus, including religiosity, can be equalized for both groups - with or without vaginismus - over time in the changing world and in life and mental factors can remain as independent variables therefore expanding our research in this direction will help us understand this disorder better. In addition, it can be considered that male hegemon culture is one of the important factors in the etiology of vaginismus. The interpretation of religion with a male -dominated language may be a result of this hegemon culture.
\end{abstract}

Keywords: vaginismus, religiosity, islam, turkey, socio-cultural features

DOI: 10.5798/dicletip.987807

Correspondence / Yazışma Adresi: Elif Aktan Mutlu, Psychiatrist Ministry of Health Bursa City Hospital, Department of Psychiatry 16110, Bursa, Turkey e-mail: aktanazer@hotmail.com 


\section{Vajinismus etiyolojisinde sosyo-kültürel özellikler ışığında dindarlığın rolü: Türkiye örneği}

\section{Öz}

Amaç: Vajinismus, Türkiye ve Ortadoğu ülkelerinde en sık görülen kadın cinsel işlev bozukluğudur. Vajinismus ile ilgili tıbbi literatüre bakıldığında, çalışmalar / hastalar Orta Doğu coğrafyasında yoğunlaşmıștır. Türkiye, Orta Doğu ile Avrupa arasında yer alan, nüfusunun çoğunluğu Müslümanlardan oluşan ve gelişmekte olan laik bir ülkedir. Etiyolojide psikososyal, kültürel, biyolojik ve cinsel nedenler dahil birçok faktör tartışılmıștır. Bir kişinin dindarlık biçimindeki dini inançları, hayatının tüm sosyal ve manevi alanlarını bir şekilde olumlu veya olumsuz etkilemektedir. Dini inançlardan en çok etkilenen yaşam alanlarından biri de pek çok tabu içeren cinsel yaşamdır. Bu çalışmada, vajinismus etiyolojisinde etkili olduğu düşünülen dini inanç düzeylerini hastalar ve sağlıklı kontroller arasında karşılaştırmayı ve diğer sosyo-kültürel özelliklerden bazılarını tartışmayı amaçladık.

Yöntemler: 49 hasta ve 37 sağlıklı gönüllü dahil edildi. Sosyodemografik veri formu, dini yaşam ölçeği ve genel cinsel mit formu ölçüm araçları olarak kullanıldı.

Bulgular: Vajinismusu olan ve olmayan katılımcılar arasında eğitim süreleri, çalışma durumları, meslekleri, ekonomik durumları, en uzun süre yaşadıkları yerler ve evlilik şekilleri açısından istatistiksel olarak anlamlı fark bulunmadı (tümü için p> 0,05). Vajinismus varlığı açısından her iki grubun inanç, duygu, davranış, bilgi ve toplam puanları arasında istatistiksel olarak anlamlı bir fark bulunmadı (tümü için p>0.05).

Sonuç: Sonuç olarak, vajinismus etiyolojisine ait sosyodemografik verilerin çoğu, dindarlık da dahil olmak üzere, her iki grup için de vajinismus olsun ya da olmasın - değișen dünyada ve yaşamda zamanla eşitlenebilir ve zihinsel faktörler bağımsız değişkenler olarak kalabilir, dolayısıyla bu yöndeki araştırmalarımız, bu bozukluğu daha iyi anlamamıza yardımcı olacaktır. Ayrıca erkek egemen kültürünün vajinismus etiyolojisindeki önemli faktörlerden biri olduğu düşünülebilir. Dinin erkek egemen bir dille yorumlanması bu baskın kültürün bir sonucu olabilir.

Anahtar kelimeler: vajinismus, dindarlık, islam, türkiye, sosyo-kültürel özellikler.

\section{INTRODUCTION}

Vaginismus is the most common female sexual dysfunction in Turkey and Middle East countries ${ }^{1}$. Looking at the medical literature related to vaginismus, studies/patients have concentrated in the Middle east geographic area $^{2}$. Turkey is a developing, secular country located between Middle East and Europe with a mostly Muslim population ${ }^{3}$. Many factors have been discussed in the etiology including psychosocial, cultural, biological and sexual causes. It does not seem possible to reduce this function to a single cause. These causes include several factors such as raising style, sexual knowledge level, religious and cultural factors, spouse attitudes and personality characteristics. New approaches emphasize the importance of etiology and recommend determining treatment options according to etiology ${ }^{4}$. Religious beliefs affect life in every area. These may include social, cultural, economic, educational, spiritual and many other areas. Religiosity is a concept that can change by time, place, culture or other socioeconomic conditions $^{3}$. While religiosity is usually examined with belief and behaviour dimensions, a religious person is defined as a person who thinks that behavior, morality and belief dimensions of life are a whole, and who lives with these dimensions ${ }^{5}$.

There are many religions in the world. Sexuality is approached from different perspectives in each religion. It has been discussed both in the arrangement of married life and social life. Sexual provisions or laws are expected to be implemented by people who believe in that religion. For example, the holiness of virginity has been emphasized and sex outside of marriage has been prohibited. There is almost no belief system that does not emphasize sexual life ${ }^{6}$. Religious beliefs of a person in the form of religiosity affect all social and spiritual areas of his/her life somewhat positively or negatively. 
One of the most affected life areas by religious beliefs is sexual life, which has a lots of taboos. Therefore, religious beliefs, thoughts, attitudes and behaviors of an individual inevitably affects the phenomenon of virginity associated with sexual life, view of sexual intercourse before or outside of marriage, and the relationship with the guilt and sinfulness that they cause in the individual 7,8 .

All of these etiological factors can be the subject of studies in the literature separately. However, the majority of studies have defined this dysfunction as an illness of "Western Countries". The place of religious beliefs in the etiology of vaginismus has been studied through sociological observations in the literature, examined within the framework of the importance given by a religion to virginity and prohibition of sexual intercourse outside of marriage, and emphasis has been placed on the guilt the intercourse created in women ${ }^{9}$. Religiosity has an important place in the literature among the etiological reasons that cause vaginismus. While starting this study, our hypothesis is that the religiousness levels of the vaginismus group are higher than those without vaginismus. However, there is no study to compare patients' religious belief levels with healthy controls.

In this study we aimed to compare religious belief levels that are thought to be effective in the etiology of vaginismus between patients and healthy controls, and to discuss them in the light of some socio-demographic data.

\section{METHODS}

A total of 49 patients who presented to Van Regional Training and Research Hospital and 37 healthy volunteers were included in the study. All participants aged 18 years and over, and agreed to participate in the study. Outpatients who applied to the psychiatry outpatient clinic were included in the study. The participants were examined by a psychiatrist. Vaginismus was diagnosed according to DSM 4 diagnostic criteria. Axis I diagnoses other than vaginismus were excluded. In both groups, those with neurological diseases that could affect their mental health were also excluded from the study. In both groups, illiterate individuals were excluded from the study. Only 4 people from the vaginismus group were not included in the study because they were illiterate, and all of the control group were literate. All participants in both groups completed the study. Volunteers in the control group were also examined by a psychiatrist, and those without axis I diagnoses were included in the study. All of the control group reported that they experienced penile penetration during coitus and were not disturbed by it. Sociodemographic data form, religious life scale and a form prepared by the researchers consisting of common sexual myths in Turkey were used as the measurement tools. Healthy volunteers were selected from hospital staff and their relatives who agreed to participate in the study. All participants stated that they believed in the religion of Islam. All participants were invited to the psychiatry outpatient clinic, their examinations were made, their written consents were obtained and the forms were filled.

Sociodemographic form included questions prepared by the researchers about general sociodemographic characteristics of the participants. The form included descriptive questions such as age, duration of marriage, form of marriage, educational status, partner's age, partner's marital status and economical status.

Sexual myths form was applied by the researchers as an 18-question form utilizing some common sexual myths in Turkey ${ }^{10}$.

Religiosity Scale: In this study, we used the 'Religious Life Scale'. This scale was developed by faculty members of Dokuz Eylul University Divinity School, Department of Religious Psychology and structured as to involve belief, emotions, behavior and knowledge dimension of religiosity in accordance with the religiosity model proposed by Glock ${ }^{11}$. The scale consists of 97 items with 31 being major and 66 filling items. The participants responded to 31 questions. The scale has 4 subdimensions as belief, emotions, 
behaviour and knowledge. Belief subscale consists of 4, emotions subscale 7 , behavior subscale 10 and knowledge subscale 10 items. Belief subscale was arranged with 3 options as agree ( 2 points), undecided (1 point) and disagree ( 0 point), and minimum score that can be obtained from the subscale was 0 and maximum score was 8. Emotions subscale consisted of 4 options as never ( 0 point), some (1 point), much ( 2 points), very much ( 3 points). The score range was $0-21$ points. Behaviour subscale included the options of never ( 0 point), sometimes ( 1 point), mostly ( 2 points), always (3 points). The minimum score that can be obtained from this subscale was 0 and the maximum score was 30 . Knowledge subscale was marked as True (T) and False (F) and each true answer was scored as 1 point. A minimum score of 0 and a maximum of 69 points could be obtained from the overall scale. Validity and reliability study of the scale was conducted by Yildiz ${ }^{12}$.

This study was approved by the Van Regional Hospital ethics committee with protocol number (2014/1). All scales and forms to be used in the study were submitted to the ethics committee, and inclusion and exclusion criteria were presented in detail.

\section{Statistical Analysis}

Statistical analysis was performed using NCSS (Number Cruncher Statistical System) 2007 software $^{13}$. When study data were evaluated; besides descriptive statistics (mean, standard deviation, median, frequency, percentage, minimum, maximum), comparison of normally distributed quantitative variables between two groups was made with Student t Test, while comparison of non-normally distributed variables was made with Mann Whitney U test. Qualitative variables were compared using Pearson's Chisquare test, Fisher-Freeman-Halton Exact test and Fisher's Exact test. Correlations between the variables were evaluated with Pearson's Correlation Analysis for normally distributed variables and Spearman's Correlation Analysis for non-normally distributed variables. $\mathrm{p}<0.05$ values were considered statistically significant. In the evaluations to be made according to the presence of vaginismus, it was determined that at least 26 cases should be present in the groups in order to show the presence of a large effect size ( $d=0.8$ ) with $80 \%$ power at the $\alpha=0.05$ level.

Consistency tests were repeated for all three scales and Crohnbach $\alpha$ values were found as 0.741 in Sexual Myths Scale and 0.812 in Religious Life Scale. These values were within very reliable, highly reliable and again highly reliable limits.

Alpha coefficients were evaluated as follows:

$0.0<0.40$ scale is not reliable.

$0.40<0.60$ scale is low-reliable.

$0.60<0.80$ scale is very reliable.

$0.80<1.00$ scale is highly reliable ${ }^{14}$.

Correlation coefficients $(r)$ were calculated as follows:

$0-0,25$ very poor, $0,26-0,49$ poor, $0,50-0,69$ average, $0,70-0,89$ good, $0,90-1,00$ very good $^{15}$.

\section{RESULTS}

In our study, there were 49 subjects with vaginismus and 37 subjects without vaginismus. There was a statistically significant difference between ages of the participants in terms of the presence of vaginismus $(\mathrm{p}=0.001 ; \mathrm{p}<0.01)$; patients with vaginismus were younger.

No statistically significant difference was found between the participants with and without vaginismus in terms of education duration, working status, occupations, economical status, longest living place and marriage form (for all $\mathrm{p}>0.05$ ). There was a statistically significant difference between marriage durations according to the presence of vaginismus $(p=0.001 ; p<0.01)$; patients with vaginismus had a shorter marriage duration. Again, there was a statistically significant difference between partner's ages according to the presence of vaginismus ( $p=0.001$; $\mathrm{p}<0.01$ ); partners of the patients with vaginismus were younger. No statistically significant difference was observed between the incidence of 
vaginismus in terms of partners' education duration $(p>0.05)$ (Table 1).

Table I: Descriptive Features According to Presence of Vaginismus

\begin{tabular}{|c|c|c|c|c|}
\hline & \multicolumn{2}{|c|}{ Vaginismus } & \multirow{3}{*}{$p$} \\
\hline & & \multirow{2}{*}{\begin{tabular}{|l|} 
No $(n=37)$ \\
$n(\%)$ \\
\end{tabular}} & \multirow{2}{*}{\begin{tabular}{|l} 
Yes (n=49) \\
$n(\%)$
\end{tabular}} & \\
\hline & & & & \\
\hline \multirow{2}{*}{$\begin{array}{l}\text { Age } \\
\text { (years) }\end{array}$} & $\begin{array}{l}\text { Min-Max } \\
\text { (Median) }\end{array}$ & $20-42(27)$ & $18-31(24)$ & ${ }^{a} 0.001 * *$ \\
\hline & Mean $\pm S D$ & $27.84 \pm 5.34$ & $23.90 \pm 3.80$ & \\
\hline \multirow{4}{*}{$\begin{array}{l}\text { Education } \\
\text { duration }\end{array}$} & Literate & $2(5.4)$ & $2(4.1)$ & ${ }^{d} 0.614$ \\
\hline & $1-5$ years & $9(24.3)$ & $8(16.3)$ & \\
\hline & $6-10$ years & $3(8.1)$ & $8(16.3)$ & \\
\hline & $\begin{array}{l}11 \text { years and } \\
\text { over }\end{array}$ & $23(62.2)$ & $31(63.3)$ & \\
\hline \multirow{2}{*}{$\begin{array}{l}\text { Working } \\
\text { status }\end{array}$} & Working & $16(43.2)$ & $30(61.2)$ & 0.098 \\
\hline & Not working & $21(56.8)$ & $19(38.8)$ & \\
\hline \multirow{4}{*}{$\begin{array}{l}\text { Economic } \\
\text { al status }\end{array}$} & Low & $1(2.7)$ & $5(10.2)$ & ${ }^{d} 0.182$ \\
\hline & Below average & $3(8.1)$ & $1(2)$ & \\
\hline & Average & $29(78.4)$ & $33(67.3)$ & \\
\hline & Above average & $4(10.8)$ & $10(20.4)$ & \\
\hline \multirow{2}{*}{$\begin{array}{l}\text { Place of } \\
\text { longest } \\
\text { living }\end{array}$} & Village/ town & $4(10.8)$ & $6(12.2)$ & ${ }^{e} 1.000$ \\
\hline & $\begin{array}{l}\text { City/ } \\
\text { metropolitan }\end{array}$ & $33(89.2)$ & $43(87.8)$ & \\
\hline \multirow{2}{*}{$\begin{array}{l}\text { Marriage } \\
\text { form }\end{array}$} & $\begin{array}{l}\text { Arranged (own } \\
\text { decision) }\end{array}$ & $14(37.8)$ & 17 (34.7) & $c 0.764$ \\
\hline & Flirting & $23(62.2)$ & $32(65.3)$ & \\
\hline \multirow{2}{*}{$\begin{array}{l}\text { Marriage } \\
\text { duration } \\
\text { (month) }\end{array}$} & $\begin{array}{l}\text { Min-Max } \\
\text { (Median) }\end{array}$ & $5-192(36)$ & $1-40(8)$ & ${ }^{b} 0.001 * *$ \\
\hline & Mean $\pm S D$ & $52.65 \pm 51.73$ & $10.92 \pm 10.30$ & \\
\hline \multirow{2}{*}{$\begin{array}{l}\text { Partner's } \\
\text { age } \\
\text { (years) }\end{array}$} & $\begin{array}{l}\text { Min-Max } \\
\text { (Median) }\end{array}$ & $24-45(31)$ & $17-34(27)$ & ${ }^{a} 0.001 * *$ \\
\hline & Mean $\pm S D$ & $31.70 \pm 5.37$ & $26.69 \pm 4.08$ & \\
\hline \multirow{3}{*}{$\begin{array}{l}\text { Partner's } \\
\text { education } \\
\text { duration }\end{array}$} & $1-5$ years & $2(5.4)$ & $4(8.2)$ & ${ }^{d} 0.636$ \\
\hline & 6-10 years & $5(13.5)$ & $10(20.4)$ & \\
\hline & $\begin{array}{l}11 \text { years and } \\
\text { over }\end{array}$ & $30(81.1)$ & 35 (71.4) & \\
\hline
\end{tabular}

A Student $t$ Test, $b$ Mann Whitney $U$ Test, $c$ Pearson Chi-square Test, $d$ Fisher-Freeman-Halton Test, e Fisher's Exact Test, ${ }^{* *} p<0.01$

Sexual myths and Religious Life Scale were grouped and compared between the participants with and without vaginismus, and no significant difference was found between both groups in terms of sexual myth levels and religious belief levels (Table 2).

Table II: Scale Scores According to the Presence of Vaginismus

\begin{tabular}{|c|c|c|c|c|c|}
\hline & & Vaginismus & & & Effect size, \\
\hline & & No $(n=37)$ & Yes $(n=49)$ & & power \\
\hline Sexual myth & scale & & & & \\
\hline & $\begin{array}{l}\text { Min-Max } \\
\text { (Median) }\end{array}$ & 3-15 (10) & 1-18 (10) & ${ }^{a} 0.263$ & \\
\hline & Mean $\pm S D$ & $9.68 \pm 3.19$ & $10.49 \pm 3.41$ & & \\
\hline Religious Lif & e Scale & & & & \\
\hline Belief & $\begin{array}{l}\text { Min-Max } \\
\text { (Median) }\end{array}$ & 7-8 (8) & 7-8 (8) & ${ }^{b} 0.732$ & \\
\hline & Mean $\pm S D$ & $7.97 \pm 0.16$ & $7,96 \pm 0.20$ & & \\
\hline Emotions & $\begin{array}{l}\text { Min-Max } \\
\text { (Median) }\end{array}$ & 6-21 (18) & 3-21 (18) & ${ }^{b} 0.676$ & \\
\hline & Mean $\pm S D$ & $17.24 \pm 3.18$ & $17.04 \pm 3.98$ & & \\
\hline Behaviour & $\begin{array}{l}\text { Min-Max } \\
\text { (Median) }\end{array}$ & 6-30 (25) & $11-30$ (26) & ${ }^{b} 0.902$ & \\
\hline & Mean $\pm S D$ & $23,59 \pm 5,52$ & $25,39 \pm 4,06$ & & \\
\hline Knowledge & $\begin{array}{l}\text { Min-Max } \\
\text { (Median) }\end{array}$ & 4-9 (6) & 3-9 (7) & ${ }^{b} 0.752$ & \\
\hline & Mean $\pm S D$ & $6.46 \pm 1.14$ & $6.51 \pm 1.60$ & & \\
\hline Total & $\begin{array}{l}\text { Min-Max } \\
\text { (Median) }\end{array}$ & 25-66 (58) & 37-67 (58) & ${ }^{b} 0.457$ & \\
\hline & Mean $\pm S D$ & $55.27 \pm 7.94$ & $56.90 \pm 6.31$ & & \\
\hline
\end{tabular}


There was no statistically significant difference terms of the presence of vaginismus $(p>0.05)$ between total scores of the sexual myth scale in (Table 3).

Table III: Distribution of the answers given to the Sexual Myth Scale

\begin{tabular}{|c|c|c|c|c|}
\hline & \multicolumn{2}{|c|}{ False } & \multicolumn{2}{|c|}{ True } \\
\hline & $n$ & $\%$ & n & $\%$ \\
\hline 1. Male always wants sex and is always ready for sex & 9 & 10.5 & 77 & 89.5 \\
\hline 2. Male should always start sexual intercourse & 47 & 54.7 & 39 & 45.3 \\
\hline 3. A woman who started making love is immoral & 75 & 87.2 & 11 & 12.8 \\
\hline 4. Making love equals sexual intercourse & 32 & 37.2 & 54 & 62.8 \\
\hline 5. Male should ejaculate as soon as possible once his penis become erect & 45 & 52.3 & 41 & 47.7 \\
\hline 6. Making love must always be natural and spontaneous, talking and thinking about making love disrupt it & 30 & 34.9 & 56 & 65.1 \\
\hline 7. All physical contacts should proceed to sexual intercourse & 60 & 69.8 & 26 & 30.2 \\
\hline 8. Men should not show their feelings & 74 & 86.0 & 12 & 14.0 \\
\hline 9. Every man should know how to enjoy every woman & 9 & 10.5 & 77 & 89.5 \\
\hline 10. Intercourse is only beautiful when both partners have orgasms together & 3 & 3.5 & 83 & 96.5 \\
\hline 11. If the partners love each other, they also know how to enjoy intercourse. & 5 & 5.8 & 81 & 94.2 \\
\hline 12. Spouses who have sexual intercourse instinctively know what the other partner is thinking and feeling & 15 & 17.4 & 71 & 82.6 \\
\hline 13. Masturbation is dirty and harmful & 38 & 44.2 & 48 & 55.8 \\
\hline 14. Masturbation is wrong during sexual intercourse & 35 & 40.7 & 51 & 59.3 \\
\hline 15. Loss of erection in penis means that he does not find his partner attractive & 54 & 62.8 & 32 & 37.2 \\
\hline 16. Fancy (dreaming) is wrong during sexual intercourse & 52 & 60.5 & 34 & 39.5 \\
\hline 17. Man or woman cannot say no to sexual intercourse & 51 & 59.3 & 35 & 40.7 \\
\hline 18. There are certain and strict rules about what is normal in making love & 42 & 48.8 & 44 & 51.2 \\
\hline
\end{tabular}

\section{Evaluations of Religious Life Scale}

Cronbach's alpha coefficient of the overall scale was found as 0.812 and the scale was found to be highly reliable. No statistically significant difference was found between the belief, emotions, behaviour, knowledge and total scores of both vaginismus and non-vaginismus groups (for all $\mathrm{p}>0.05$ ) (Table 4 ). 
Table IV: Distribution of the Answers Given to the Religious Life Scale

\begin{tabular}{|c|c|c|c|c|c|c|c|c|}
\hline \multirow{2}{*}{ Belief dimension } & & & \multicolumn{2}{|c|}{ Disagree } & \multicolumn{2}{|c|}{ Undecided } & \multicolumn{2}{|c|}{ Agree } \\
\hline & & & $n$ & $\%$ & n & $\%$ & n & $\%$ \\
\hline \multicolumn{3}{|l|}{ 1. There is Allah } & 0 & 0 & 0 & 0 & 86 & 100 \\
\hline \multicolumn{3}{|l|}{ 2. Hz. Muhammad is the prophet of Allah } & 0 & 0 & 0 & 0 & 86 & 100 \\
\hline \multicolumn{3}{|l|}{ 3. There will be an eternal life called afterlife after death } & 0 & 0 & 2 & 2.3 & 84 & 97.7 \\
\hline \multicolumn{3}{|l|}{ 4. The Quran is the holy book sent by Allah } & 0 & 0 & 0 & 0 & 86 & 100 \\
\hline \multirow{2}{*}{ Emotions dimension } & \multicolumn{2}{|c|}{ Never } & \multicolumn{2}{|c|}{ Some } & \multicolumn{2}{|c|}{ Much } & \multicolumn{2}{|c|}{ Very much } \\
\hline & $n$ & $\%$ & $n$ & $\%$ & $n$ & $\%$ & n & $\%$ \\
\hline $\begin{array}{l}\text { 5. While worshiping, I feel emotional thinking that I am in the presence of } \\
\text { Allah }\end{array}$ & 1 & 1.2 & 17 & 19.8 & 22 & 25.6 & 46 & 53.5 \\
\hline 6. While praying, I feel relief, hoping that Allah will accept my prayer & 2 & 2.3 & 9 & 10.5 & 23 & 26.7 & 52 & 60.5 \\
\hline $\begin{array}{l}\text { 7. When I enter a large mosque, I feel a spiritual atmosphere that I have not } \\
\text { always experienced }\end{array}$ & 6 & 7.0 & 14 & 16.3 & 28 & 32.6 & 38 & 44.2 \\
\hline 8. When I help someone, I feel enthusiasm and peace inside me & 1 & 1.2 & 6 & 7.0 & 20 & 23.3 & 59 & 68.6 \\
\hline 9. When I think I have sinned, I feel regret and restlessness & 0 & 0 & 7 & 8.1 & 21 & 24.4 & 58 & 67.4 \\
\hline $\begin{array}{l}\text { 10. When I encounter a situation that reminds me death, I feel shuddered } \\
\text { and excited by thinking about what can happen to me in the afterlife }\end{array}$ & 1 & 1.2 & 11 & 12.8 & 37 & 43.0 & 37 & 43.0 \\
\hline $\begin{array}{l}\text { 11. I admire the might of Allah in the face of everything being very orderly } \\
\text { in nature }\end{array}$ & 0 & 0 & 1 & 1.2 & 19 & 22.1 & 66 & 76.7 \\
\hline \multirow{2}{*}{ Behaviour dimension } & \multicolumn{2}{|c|}{ Never } & \multicolumn{2}{|c|}{ Sometimes } & \multicolumn{2}{|c|}{ Mostly } & \multicolumn{2}{|c|}{ Always } \\
\hline & $n$ & $\%$ & $n$ & $\%$ & $n$ & $\%$ & n & $\%$ \\
\hline 12. I fulfill the worships due to my belief & 4 & 4.7 & 35 & 40.7 & 33 & 38.4 & 14 & 16.3 \\
\hline 13. I refrain from drinking because it is forbidden in religion & 1 & 1.2 & 5 & 5.8 & 7 & 8.1 & 73 & 84.9 \\
\hline 14. I avoid gambling, since it is a sin & 2 & 2.3 & 1 & 1.2 & 2 & 2.3 & 81 & 94.2 \\
\hline 15. I avoid adultery, because it is forbidden in my religion & 1 & 1.2 & 4 & 4.7 & 5 & 5.8 & 76 & 88.4 \\
\hline
\end{tabular}




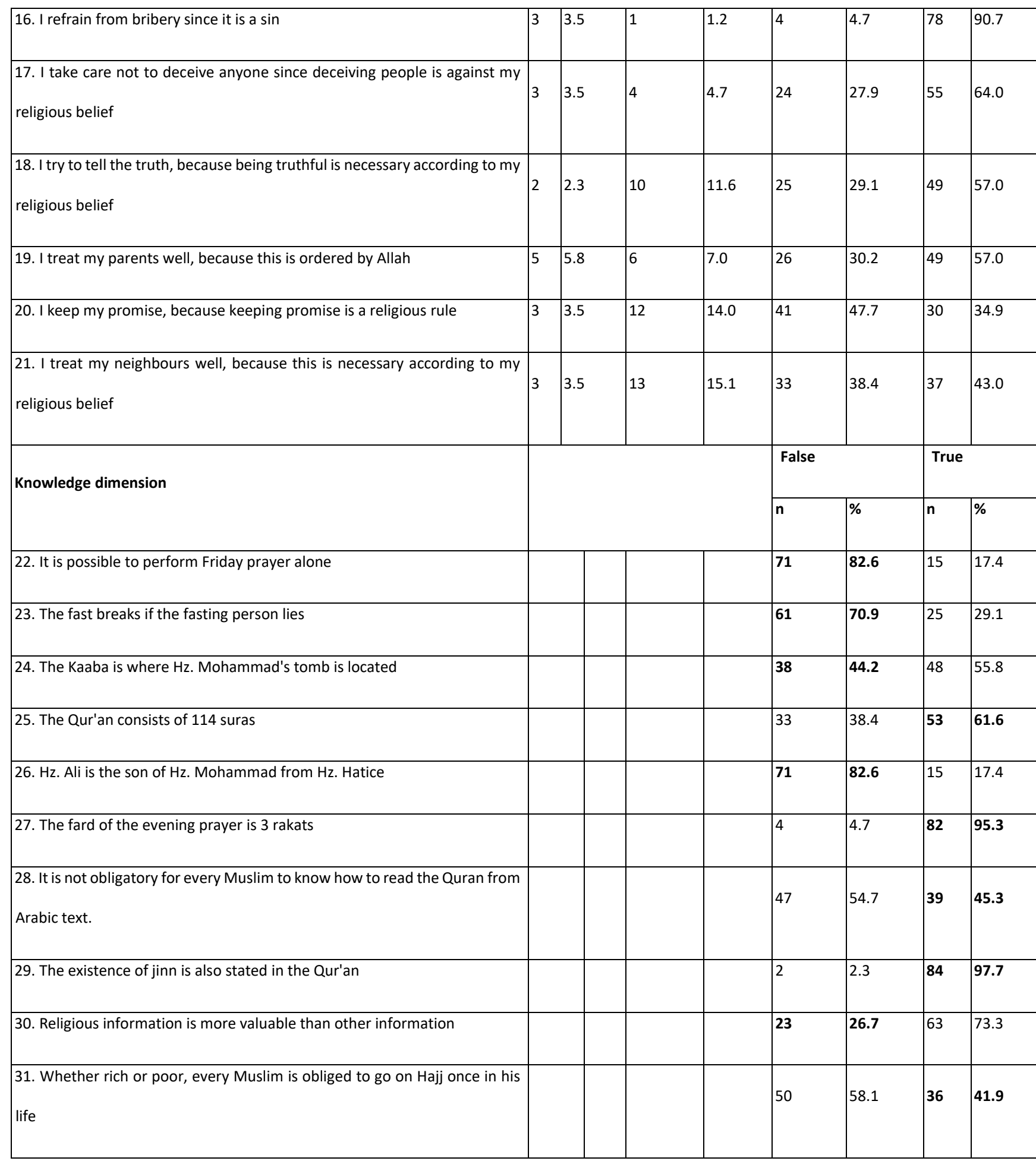

\section{DISCUSSION}

When both groups were evaluated in terms of age, participants in the vaginismus group were younger. Since first sexual intercourse is encountered during first years of marriage, seeing a physician also occurs in this period. The mean age at presentation was about 23 years in our patient group, the mean duration of 
marriage was nearly 10 months in this group. Mean ages of patients with vaginismus in studies are usually similar to our result ${ }^{16}$. Similar sociodemographic features between both groups might decrease limitations due to age differences somewhat, but the two groups were not homogenous as a limitation.

Working status was one of the titles examined in vaginismus. It can be said that working women feel themselves more free, have more communication facilities, open more to the world, and access right to information more easily ${ }^{17}$. This can be thought to decrease vaginismus by increasing sexual knowledge levels, increasing communication with men in social settings etc. However, in our study no significant difference was found between both groups in terms of working. In the literature, the rates of working/not-working among the patients with vaginismus were similar to our results $^{18}$. In other words, we can not make a suggestion that vaginismus is the disease of working women or not-working women. We can say that working is not protective against vaginismus in this population. In fact, in a study from our country on religious and working women, the rate of these women becoming visible in society has risen, but their lifestyle continued in a paternalistic form ${ }^{19}$. However, in our study such advantages of working seem to be absent. This may show that women do not have access to the mentioned freedoms in working life. This may be resulted from working life, which has been established in a male dominant nature. Sociologic, political and economic factors other than religious beliefs may eliminate or reduce the advantages brought by working life to women ${ }^{20}$.

Another result of our study was lack of significant difference between both groups in terms of educational status. At least $60 \%$ of the participants in the both groups received education for 11 years and over. Looking at our study period, only one fifth of women in Turkey had an educational level of high school and higher ${ }^{21}$. Whereas in our study, more than $60 \%$ of the participants in the vaginismus group and other group- received education for 11 years and over. There are numerous studies reporting that vaginismus is caused by lack of education and knowledge ${ }^{22}$. However, lack of sexual education courses in the Turkish education system ${ }^{23}$ may eliminate the positive contribution of being educated. Although women with a high educational level are also seen to have vaginismus ${ }^{24}$ in our study, knowledge level of the participants could not be exactly revealed, and this could not be compared with religiosity as a limitation. However similar religiosity and educational levels between both groups may be an important indicator showing that the effect of religious belief on vaginismus is less than it is thought.

Cities were the places of longest living in both groups. When the incidence of vaginismus was examined in terms of living in rural or urban areas, studies in the literature have reported similar results for both locations ${ }^{25}$. In our study, it does not seem possible to conclude that living in a city brings advantages for sexual life. We attributed this to unhealthy urbanization. Migration to urban areas from rural areas, and maintaining rural/ paternalistic culture are among the most important causes of this. Van province where this study was conducted is located in the most underdeveloped region of Turkey in terms of urbanization ${ }^{26}$. However, in our study migration data of the patients were missing, as a limitation.

Marriage forms have also been subjected to many studies in the literature. Studies have reported similar results with our study ${ }^{16}$. Looking at Turkey, the rate of arranged marriage with their own decision accounts for about $40 \%$ of all marriages. In our study, the number of patients married with this form was close to this rate (approximately 37\%). 
There was no significant difference between both groups in terms of sexual myths. In a recent study, the levels of sexual myths were shown to be not high among the couples that prepared for marriage 27 . In fact, the general opinion is that patients with vaginismus have more sexual myths, although studies in the literature did not report a definitive conclusion on this issue.

Religiosity level was similar between the two groups. Both groups have many similar characteristics including educational level, working status, partners' educational level, income level, marriage forms and the regions of living. At the same time, the levels of sexualt myths were similar between the two groups. The participants in the group without vaginismus were older and their marriage durations were longer. Religiosity concept is affected by many factors. Some of these factors include age, gender, marital status, socioeconomic level, living in urban/rural areas and educational level. Religiosity is seen more commonly in married persons and women as age and living in a rural area increase, while religiosity level decreases as educational level and living in an urban area increase ${ }^{28}$. However, in our study religiosity level seems to be not affected by variables such as age, educational level, place of living, and economical status. In this case, it can be said that one of the important factor in socio-cultural dimension of the etiology is a paternalistic social structure.

In fact there are publications in the psychiatry literature supporting this opinion ${ }^{29}$. In the literature, we can think that the maledominated culture may underlie the determination that religiosity is effective as an etiological reason and this is confused with religiosity. Ultimately in a textbook investigating the relationship of religion in paternalistic societies; the author stated that universal problems of Arabian women such as sexuality, marriage, sexual abuse, devastation of sexual organ and divorce are not resulted from Islamic values, but from paternatistic culture ${ }^{30}$. However, the lack of sufficient number of cases in our study is a limitation and large study populations are needed.

\section{CONCLUSIONS}

In our study, it was observed that there was no statistical difference between the groups with and without vaginismus in terms of sociodemographic data such as education level, employment status, marriage style, education status of the spouse, the shape of the city of residence, sexual myths. In addition, according to the results of the study, it is seen that the thesis "the level of religiosity is higher in vaginismus patients" in our hypothesis is not confirmed. Vaginismus is a disorder in which many social and mental factors play a role in its etiology. However, the similar sociodemographic characteristics of both groups - including their level of religiosity prompted us to consider other psychiatric etiological factors. Investigation of psychiatric factors in the etiology of vaginismus is not among the objectives of this study. This article contributes to the world of literature in terms of showing that the view "religiousness is one of the factors contributing to the formation of vaginismus" may not be valid. In conclusion, most of the sociodemographic data involved in the etiology of vaginismus, including religiosity, can be equalized for both groups - with or without vaginismus - over time in the changing world and in life and mental factors can remain as independent variables therefore expanding our research in this direction will help us better understand this disorder.

Ethics Committee Approval: This study was approved by the Van Regional Hospital ethics committee with protocol number (2014/1). All scales and forms to be used in the study were submitted to the ethics committee, and inclusion and exclusion criteria were presented in detail. 
Declaration of Conflicting Interests: The authors declare that they have no conflict of interest.

Financial Disclosure: No financial support was received.

\section{REFERENCES}

1. Dağ H, Dönmez S, Kavlak O. Kadın cinselliğinin gizlenen yönü: Vajinismus ve hemşirenin rolü. Sürekli Tıp Eğitimi Dergisi. 2012; 21: 43-7.

2. Michetti P, Silvaggi M, Fabrizi A, et al. Unconsummated marriage: can it still be considered a consequence of vaginismus? Int J Impot Res. 2014; 26: 28-30.

3. Çarkoğlu A, Kalaycıoğlu E. Türkiye'de dindarlık: Uluslararası bir karşılaştırma. 2009.

4. Jeng C-J. The pathophysiology and etiology of vaginismus. Taiwanese J Obstet Gynecol. 2004; 43: 10-5.

5. Köroğlu CZ. Türkiye'de dini hayatın incelenmesi: Bütüncül bir yaklaşım. Gümüşhane Üniversitesi İlahiyat Fakültesi Dergisi. 2012; 1: 82-102.

6. Adamczyk A, Hayes BE. Religion and sexual behaviors: Understanding the influence of Islamic cultures and religious affiliation for explaining sex outside of marriage. American Sociological Review. 2012; 77: 723-46.

7. Reynolds DI. Religious influence and premarital sexual experience: critical observations on the validity of a relationship. Journal for the scientific study of religion. 1994: 382-7.

8. Wink W: Homosexuality and Christian faith: Questions of conscience for the churches: Fortress Press; 1998.

9. Zgueb Y, Ouali U, Achour R, Jomli R, Nacef F. Cultural aspects of vaginismus therapy: a case series of Arab-Muslim patients. The Cognitive Behaviour Therapist. 2019; 12.

10. Güneş M, Akçali H, Onur D, et al. Prematür ejakülasyon olgularında cinsel mitlere inanma düzeyi. Dicle Tıp Dergisi. 2016; 43: 319-28.

11. Glock CY. On the study of religious commitment. 1962.
12. Yıldız M. Ölüm kaygısı ve dindarlık. İzmir: İzmir İlahiyat Vakfı Yayınları. 2006.

13. Hintze J: NCSS 2007. NCSS, LLC. Kaysville, Utah, USA. In.; 2007.

14. Karagöz Y. SPSS 21.1 Uygulamalı Biyoistatistik, 1. basım. Nobel Akademik Yayınclık. 2014; 698.

15. Akgül A, Çevik O: İstatistiksel Analiz Teknikleri "SPSS'te İşletme Yönetimi Uygulamaları, Ankara, Emek Ofset Ltd. In. Şti; 2003.

16. Doğan S, Saraçoğlu GV. Yaşam Boyu Vajinismusu Olan Kadınlarda Cinsel Bilgi, Evlilik Özellikleri, Cinsel İşlev ve Doyumun Değerlendirilmesi. Trakya Univ Tıp Fak Derg. 2009; 26: 151-8.

17. Özçelik MK. Çalışma hayatında kadının yeri ve kariyer gelişim engelleri. Akademik Sosyal Araştırmalar Dergisi, 2017;5: 49-70.

18. Yıldırım EA, Hacıoğlu Yıldırım M, Karaş H. Yaşam Boyu Vajinismus Tanısı Konulan Kadınlarda Depresyon ve Anksiyete Bozukluklarının Yaygınlığı ve Cinsel İşlevlerle İlişkisi. Turk Psikiyatri Dergisi. 2019; 30: 9-15.

19. Can Y. Ücretli bir işte çalışmanın kadının sosyal konumuna etkisi. Academic Review of Economics \& Administrative Sciences. 2015; 8: 13-26.

20. Aydın S. Türkiye'de Kadının İstihdamı ve Kadına Dair Sosyal Güvenlik Uygulamaları. Çankırı Karatekin Üniversitesi Sosyal Bilimler Enstitüsü Dergisi. 2016; 7: 243-58.

21. Özaydınlık K. Toplumsal cinsiyet temelinde Türkiye'de kadın ve eğitim. Sosyal Politika Çalışmaları Dergisi. 2014; 33: 94-112.

22. Fadul R, Garcia R, Zapata-Boluda R, et al. Psychosocial correlates of vaginismus diagnosis: A case-control study. J Sex Marital Ther. 2019; 45: 7383.

23. Yücesan A, Alkaya SA. Okullarda Göz Ardı Edilen Bir Konu: Cinsel Sağlık Eğitimi. SDÜ Tıp Fak Derg. 2018; 25: 200-9.

24. Akhavan-Taghavi MH, Asghari-Moghaddam MA, Froutan SK, Jadid-Milani M. Vaginismus in Iran: A single center report of 7 years experience. Nephrourol mon. 2015; 7: e30077. 
25. Özdel 0 , Tümkaya $S$, Levent $\mathrm{N}$, ve ark. Bilişsel davranışçı yöntemlere dayalı cinsel terapinin vajinismuslu kadınlar ve eşlerinin cinsel sorunları üzerindeki etkileri. Anatolian Journal of Psychiatry/Anadolu Psikiyatri Dergisi. 2013;14; 2: 129-135.

26. Dücan E. Türkiye'de iç göçün sosyo-ekonomik nedenlerinin bölgesel analizi. Ekonomik ve Sosyal Araştırmalar Dergisi. 2016; 12: 167-83.

27. Kilci Ş, Özsoy S. Evlilik hazırlığı yapan çiftlerin cinsel mitlere inanma durumları ve etkileyen faktörler. Kadın Sağlığı Hemşireliği Dergisi. 2018; 5: 1-28.

28. Kurt A. Dindarlığı etkileyen faktörler. Uludağ Üniversitesi İlahiyat Fakültesi Dergisi. 2009; 18: 126.

29. Dağdeviren N, Set T, Aktürk Z, Öztora S. Sexual activity trends of Turkish adolescents. Turkiye Klinikleri J Med Sci. 2011; 31: 823-9.

30. El Saadawi N, Sa'dāwī N: The hidden face of Eve: Women in the Arab world: Zed Books; 2007. 